\title{
Cryptic diversity in an Atlantic Forest malaria vector from the mountains of South-East Brazil
}

\author{
Guilherme de Rezende Dias' ${ }^{1}$, Thais Tenorio Soares Fujii' ${ }^{2,3}$, Bernardo Fernandes Fogel2,3, \\ Ricardo Lourenço-de-Oliveira ${ }^{4,10}$, Teresa Fernandes Silva-do-Nascimento ${ }^{4}$, André Nóbrega Pitaluga ${ }^{5,10}$, \\ Carlos José Carvalho-Pinto ${ }^{6,10}$, Antonio Bernardo Carvalho 7,10, Alexandre Afrânio Peixoto 3,10 \\ and Luísa Damazio Pitaluga Rona ${ }^{8,9,10^{*}}$
}

\begin{abstract}
Background: Anopheles (Kerteszia) cruzii is the primary vector of human and simian malarias in Brazilian regions covered by the Atlantic Rainforest. Previous studies found that An. cruzii presents high levels of behavioural, chromosomal and molecular polymorphisms, which led to the hypothesis that it may be a complex of cryptic species. Here, An. cruzii specimens were collected in five sites in South-East Brazil located at different altitudes on the inner and coastal slopes of two mountain ranges covered by Atlantic Rainforest, known as Serra do Mar and Serra da Mantiqueria. Partial sequences for two genes (Clock and cpr) were generated and compared with previously published sequences from Florianópolis (southern Brazil). Genetic diversity was analysed with estimates of population structure $\left(F_{S T}\right)$ and haplotype phylogenetic trees in order to understand how many species of the complex may occur in this biome and how populations across the species distribution are related.

Results: The sequences from specimens collected at sites located on the lower coastal slopes of Serra do Mar (Guapimirim, Tinguá and Sana) clustered together in the phylogenetic analysis, while the major haplotypes from sites located on higher altitude and at the continental side of the same mountains (Bocaina) clustered with those from Serra da Mantiqueira (Itatiaia), an inner mountain range. These two An. cruzii lineages showed statistically significant genetic differentiation and fixed characters, and have high $F_{S T}$ values typical of between species comparisons. Finally, in Bocaina, where the two lineages occur in sympatry, we found deviations from Hardy-Weinberg equilibrium due to a deficit of heterozygotes, indicating partial reproductive isolation. These results strongly suggest that at least two distinct lineages of An. cruzii (provisorily named "Group 1" and "Group 2") occur in the mountains of South-East Brazil.

Conclusions: At least two genetically distinct An. cruzii lineages occur in the Atlantic Forest covered mountains of South-East Brazil. The co-occurrence of distinct lineages of An. cruzii (possibly incipient species) in those mountains is an interesting biological phenomenon and may have important implications for malaria prevalence, Plasmodium transmission dynamics and control.
\end{abstract}

Keywords: Anopheles (Kerteszia) cruzii, Population genetics, Mosquitoes, Cryptic species, Speciation, Malaria

\footnotetext{
* Correspondence: luisa.rona@imperial.ac.uk; luisa.rona@ufsc.br

${ }^{8}$ Department of Life Sciences, Imperial College London, London, UK

${ }^{9}$ Universidade Federal de Santa Catarina, BEG, CCB, Florianópolis, SC, Brazil

Full list of author information is available at the end of the article
}

(c) The Author(s). 2018 Open Access This article is distributed under the terms of the Creative Commons Attribution 4.0 International License (http://creativecommons.org/licenses/by/4.0/), which permits unrestricted use, distribution, and reproduction in any medium, provided you give appropriate credit to the original author(s) and the source, provide a link to the Creative Commons license, and indicate if changes were made. The Creative Commons Public Domain Dedication waiver (http://creativecommons.org/publicdomain/zero/1.0/) applies to the data made available in this article, unless otherwise stated. 


\section{Background}

Autochthonous malaria transmission in Brazil is currently reported outside the Amazon region in areas covered by the Atlantic Rainforest, where vectors, humans and nonhuman primates co-exist $[1,2]$. In this biome, one of world's top biodiversity hotspots [3-6], the main vectors are Anopheles Meigen, 1818 mosquitoes of the subgenus Kerteszia Theobald, 1905, which uses Bromeliaceae watertank plants as breeding sites [2, 7, 8]. Anopheles (Kerteszia) cruzii Dyar \& Knab, 1908, known for its role as vector of the "bromeliad malaria" since the early twentieth century $[9,10]$, is considered the primary vector of human and simian malaria currently occurring in South $(\mathrm{S})$ and South-East (SE) Brazilian regions [2, 11].

In the last 50 years several studies documented that An. cruzii populations from different regions of the country show great behavioural [12], morphological [8, 13], chromosomal [14-17] and molecular [18-24] polymorphism, leading to the hypothesis of $A n$. cruzii being a complex of cryptic species. In Rio de Janeiro (RJ), Brazil's third most densely populated state with 16 million habitants [25], more than 1700 malaria cases were reported from 1990 to 2015, mostly due to transmission by An. cruzii [1]. However, in spite of $A n$. cruzii historical importance as a malaria vector and the continuous occurrence of autochthonous malaria cases in RJ, few studies have investigated the genetic diversity of this species in the state [2]. Research to date has tended to focus on comparing individuals from RJ mountains with those from other Brazilian states rather than investigating the genetic diversity among distinct sites within the state. A previous study using allozymes showed that a population from Nova Iguaçu, located near Tinguá, RJ, on the coastal side of Serra do Mar (a mountain range running parallel to the Atlantic Ocean from RJ to the South of Brazil) is genetically similar to the Florianópolis population, in the South Brazilian region; these localities are $\sim 800 \mathrm{~km}$ apart [18].

On the other hand, multilocus DNA sequencing studies found evidence for two sympatric independent lineages, both of them distinct from lineages of other Brazilian states, occurring in Itatiaia, a site in the Serra da Mantiqueira mountains, which is located in the inner North-West of the state, separated from Serra do Mar by the Paraíba Valley [22, 24] (Fig. 1). However, since these studies were conducted separately and under different methodologies, the relationship between Serra da Mantiqueira and Serra do Mar populations remain unclear. Moreover, data from RJ are restricted to a small range of the $A n$. cruzii distribution in the state and no further investigations have been made to understand the genetic diversity of the complex in this region.

The co-occurrence of more than one lineage of $A n$. cruzii in the mountains of South-East Brazil may have important implications for malaria control, since they may be differentially involved in malaria transmission. Thus, three questions remain unsolved: (i) How many evolutionarily independent lineages of $A n$. cruzii exists in the mountains of South-East Brazil and where do they occur? (ii) What is the relationship between An. cruzii individuals from distinct sites within the biome? (iii) If more than one lineage occur in South-East Brazil, which processes may have played a role in their differentiation? In order to answer these questions, this work analysed the genetic diversity of $A n$. cruzii individuals from four sites covering the distribution of the Atlantic Forest throughout RJ, and one site in São Paulo's Serra da Bocaina, and compared the genetic variability of these five populations from South-East Brazil to previously published data from Florianópolis (southern Brazil) [22, 24].

Partial fragments of cpr (211 bp) and Clock genes (224 bp) were used in this study, since they have previously been shown to be good markers for identification of differentiating lineages in An. cruzii [21, 22, 24] and also in the Anopheles triannulatus [26] complexes of cryptic species. The cpr gene (NADPH cytochrome P450 reductase), has a putative function in Drosophila odorant clearance [27]. Since olfactory cues may have important influence in mate recognition [28], cpr may be important in sexual isolation between closely related species. The Clock gene encodes a transcription factor important in the control of dipteran circadian cycles [29]. Circadian cycle genes have been useful in the identification of cryptic diversity in African anophelines [30] and other dipteran groups such as fruit flies [31] and sand flies [32]. Furthermore, since variability in daily rhythms have an influence on malaria transmission by anophelines [33], knowledge regarding divergence in this kind of molecular marker may lend to useful insights in to malaria dynamics of the Atlantic Forest.

Our results with these two markers (cpr and Clock) strongly suggest that there are at least two independent lineages of An. cruzii in the mountains of South-East Brazil.

\section{Methods \\ Sampling sites, mosquito collection and morphological identification}

Five sites in the Atlantic Forest areas of RJ and São Paulo (SP) States (both in South-East Brazil) were sampled between 2012 and 2013 (Fig. 1). Four of them are located in the Serra do Mar mountains, which extend for $1500 \mathrm{~km}$ from the South to South-East regions along the Brazilian coast: Bocaina $\left(23^{\circ} 1^{\prime} 26.87^{\prime \prime S}, 44^{\circ} 43^{\prime} 6.47^{\prime \prime W}\right)$, Tinguá $\left(22^{\circ} 35^{\prime} 31.30^{\prime \prime S}, 43^{\circ} 26^{\prime} 8.27^{\prime \prime W}\right)$, Guapimirim $\left(22^{\circ}\right.$ $\left.30^{\prime} 30.72^{\prime \prime S}, 43^{\circ} 0^{\prime} 36.30^{\prime \prime W}\right)$ and Sana $\left(22^{\circ} 24^{\prime} 0.00^{\prime \prime S}, 42^{\circ}\right.$ $\left.10^{\prime} 60.00^{\prime \prime} \mathrm{W}\right)$. The fifth collection site was Itatiaia $\left(22^{\circ}\right.$ $\left.27^{\prime} 46.74^{\prime \prime S}, 44^{\circ} 35^{\prime} 33.55^{\prime \prime W}\right)$, located at $900 \mathrm{~m}$ above sea level in Serra da Mantiqueira, an inner mountain range 

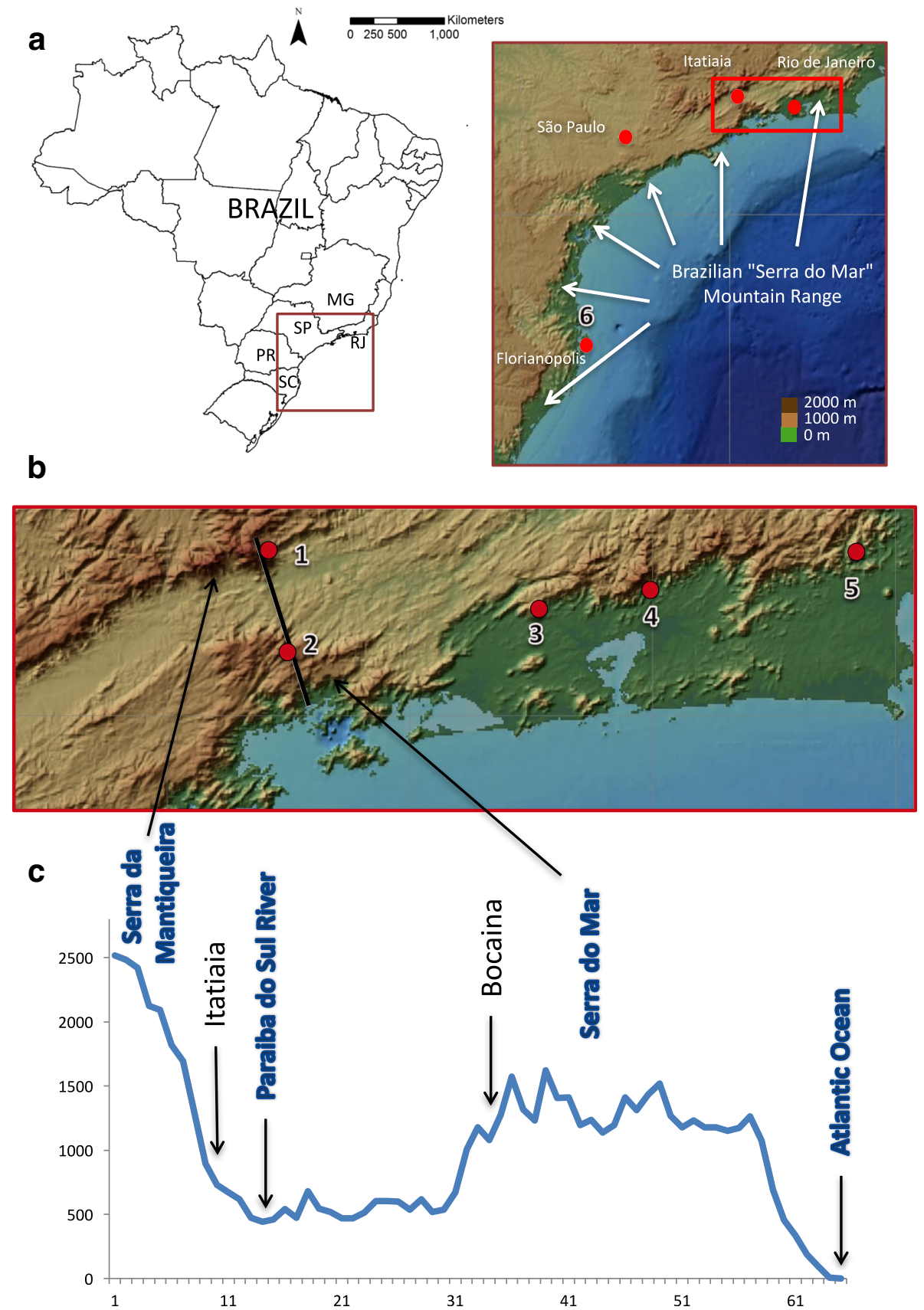

Fig. 1 Anopheles cruzii collection sites and altitude profile in South-East Brazilian Atlantic Rainforest. a Map of Brazil showing the extension of the Serra do Mar mountain range throughout the South/South-East Brazillian coastline. b Magnification of the red box from (a) displaying the Paraiba Valley between Serra da Mantiqueira and Serra do Mar. The black line in (b) shows the terrain altitude profile (c) crossing from the Serra da Mantiqueira to the Atlantic Ocean. The collection sites are labelled as follows: 1, Itatiaia; 2, Bocaina; 3, Tinguá; 4, Guapimirim; 5, Sana; 6, Florianópolis. Sequences from Florianópolis (6), located in the Brazilian South Region, were retrieved from GenBank and included in the analysis for comparison. The altitude profile points are $1.25 \mathrm{~km}$ from each other and displays a horizontal scale of 1:500,000 and vertical scale of 1:50,000. (Source: Instituto Brasileiro de Geografia e Estatística - IBGE \& NOAA)

extending through SP, RJ and Minas Gerais States. Serra do Mar and Serra da Mantiqueira are separated by the Paraíba river valley. Bocaina is located on a plateau on the continental side of the Serra do Mar 1500 m above sea level, while Guapimirim, Sana and Tinguá are located on the coastal slopes of Serra do Mar below $600 \mathrm{~m}$.

Adults and immatures of An. cruzii were collected as follows. The water collected from each bromeliad was kept in separate recipients and taken to the laboratory 
until the adults emerged. Additionally, adult mosquitoes were collected starting an hour before sunset and ending 2 hours after dusk (17:00 h to 20:00 h). Species identification was carried out using morphological identification keys [34]. Briefly, the morphological characters used to diagnose An. cruzii adults were: scutum with four dark longitudinal lines, fifth hind tarsomeres dark scaled on at least $50 \%$ at base, with an apical white band, wing vein R 4 + 5 white-scaled except for a small dark spot at the base and another at the apex. After identification, adult mosquitoes were kept in $95 \%$ ethanol at $-20{ }^{\circ} \mathrm{C}$ for DNA extraction. The data for source (adult or reared in the laboratory) and sex of each sample are shown in Additional file 1: Table S1.

\section{Molecular analysis}

The cpr and Clock partial gene sequences from Florianópolis and some sequences from Itatiaia (cpr gene: Ita02 to Ita12; Clock gene: Ita02 to Ita13) have already been published (GenBank accession numbers GU072619-GU072646 and GU072709-GU072730 for cpr; JX129234-JX129257 and GU016402-GU016425 for Clock; see Additional file 2 for details). These sequences were added to the study dataset in order to better understand how populations in RJ are related to those from other Brazilian sites which previously showed divergence when compared to Itatiaia [21-24]. The additional sequences from Itatiaia (10 mosquitoes for cpr and 8 for Clock) as well as those from Tinguá (10 mosquitoes for both genes), Guapimirim (16 mosquitoes for cpr and 9 for Clock), Sana (12 mosquitoes for $c p r$ and 9 for Clock) and Bocaina (12 mosquitoes for $c p r$ and 16 for Clock) were obtained by PCR, cloning and sequencing as described below. An alignment of all sequences for each gene is presented in Additional file 2.

Genomic DNA was extracted from each individual mosquito according to Jowett [35] and used in PCR reactions carried out in an Eppendorf Mastercycler ${ }^{\bullet}$ thermocycler (Westbury, USA) using the proofreading Pfu DNA polymerase (Biotools, Madrid, Spain) and previously described primers $[21,24]$. PCR products were purified and cloned using CloneJET ${ }^{\mathrm{\tau м}}$ PCR Cloning Kit (Fermentas Life Sciences, Carlsbad, USA). Sequencing of positive clones was carried out in an ABI Prism 3730 DNA sequencer at the Oswaldo Cruz Institute using the ABI Prism Big Dye Terminator Cycle Sequencing Ready Reaction kit (Applied Biosystems, Foster City, USA). The identity of the cloned fragments was determined by BlastX analysis against the NCBI $\mathrm{nr}$ database (http:// www.ncbi.nlm.nih.gov/BLAST/). At least 12 clones were sequenced for each mosquito to mitigate PCR errors, and allow the identification of the two alleles. The sequences were then edited and consensus sequences representing the two alleles were generated. The individuals were classified as homozygotes when only one haplotype was observed among the twelve sequences. The sequences were submitted to the GenBank database under the accession numbers KT724974-KT725197.

\section{DNA sequence analysis and haplotype genealogies}

DNA sequences were aligned with ClustalX [36] and phylogenetic trees were constructed for each gene under the Bayesian Inference method using MrBayes v.3.2.5 [37, 38]. The best-fit substitution models F81 $+\mathrm{G}$ (Clock gene) and SYM + G (cpr gene) were selected following the BIC criterion as implemented in JModelTest [39]. Indel information was included in the analysis after coding gaps into a binary matrix using FastGap software [40]. Analysis ran for $5,000,000$ generations (MCMC - 'burn-in' = 25\%) from two independent random trees to generate a convergence diagnostic. The final trees presented here are the consensus between the two final trees generated for each gene. Results from all phylogenetic analyses were viewed in FigTree v.1.4.2 [41]. $\mathrm{P}_{\mathrm{RO}} \mathrm{S}_{\mathrm{EQ}}$ v.2.91 [42] and Arlequin v.3.11 [43] software were used to obtain pairwise estimates of population differentiation [44]. The comparison of genetic distances, estimated by pairwise $F_{S T}$, with geographical distances by Mantel test [45] was performed with the ade4 package [46] using R Software v.3.3.2 [47].

\section{Results}

A total of 152 sequences (two alleles from each individual) were analysed for the Clock gene (32 sequences from Bocaina, 18 from Guapimirim, 40 from Itatiaia, 18 from Sana, 20 from Tinguá and 24 from Florianópolis). For the cpr gene, a total of 170 sequences were obtained (again the two alleles from each mosquito; 24 sequences from Bocaina, 32 from Guapimirim, 42 from Itatiaia, 24 from Sana, 20 from Tinguá and 28 from Florianópolis). Sequences from the $c p r$ gene were 211 bp long and sequences from Clock were 224 bp long. Both loci include one intron that show a number of indels. All base substitutions were silent or occurred within the introns. An alignment of all sequences for each gene is presented in Additional file 2.

\section{Population structure}

Table 1 shows the pairwise $F_{\mathrm{ST}}$ estimates for Clock and cpr genes. The highest $F_{\mathrm{ST}}$ values, all of them statistically significant $(P<0.005)$, were found in the comparisons between Itatiaia and Bocaina, with the other four populations from Florianópolis, Guapimirim, Tinguá and Sana $\left(F_{\mathrm{ST}}\right.$ between $0.423-0.734$ for Clock and between $0.388-0.733$ for $c p r$ ). Such differentiation is unexpected within a single evolutionary lineage: it has been proposed that $F_{S T}$ values above 0.35 correspond to 
Table 1 Genetic and geographical distances between Anopheles cruzii populations. Pairwise $F_{S T}$ (estimates of population differentiation) and $P$-values (significance of $F_{S T}$ values evaluated by 1000 random permutations) were calculated between sequences from individuals of distinct localities

\begin{tabular}{|c|c|c|c|c|c|}
\hline \multirow[t]{2}{*}{ Population/Gene } & \multicolumn{2}{|l|}{ Clock } & \multicolumn{2}{|l|}{$c p r$} & \multirow[t]{2}{*}{ Distance $(\mathrm{km})^{a}$} \\
\hline & $F_{S T}$ & $P$-value & $F_{S T}$ & $P$-value & \\
\hline $\begin{array}{l}\text { Guapimirim vs } \\
\text { Florianópolis }\end{array}$ & 0.001 & 0.315 & 0.244 & $<0.001$ & 785 \\
\hline Tinguá vs Guapimirim & 0.004 & 0.346 & 0.035 & 0.092 & 45 \\
\hline Tinguá vs Florianópolis & 0.008 & 0.320 & 0.322 & $<0.001$ & 748 \\
\hline Tinguá vs Sana & 0.012 & 0.270 & 0.160 & 0.009 & 130 \\
\hline Guapimirim vs Sana & 0.063 & 0.073 & 0.124 & $<0.001$ & 86 \\
\hline Sana vs Florianópolis & 0.083 & 0.009 & 0.298 & $<0.001$ & 854 \\
\hline Bocaina vs Itatiaia & 0.013 & 0.089 & 0.273 & $<0.001$ & 64 \\
\hline Bocaina vs Guapimirim & 0.423 & $<0.001$ & 0.395 & $<0.001$ & 184 \\
\hline Bocaina vs Tinguá & 0.429 & $<0.001$ & 0.446 & $<0.001$ & 140 \\
\hline Bocaina vs Sana & 0.454 & $<0.001$ & 0.388 & $<0.001$ & 269 \\
\hline Bocaina vs Florianópolis & 0.470 & $<0.001$ & 0.516 & $<0.001$ & 628 \\
\hline Itatiaia vs Guapimirim & 0.673 & $<0.001$ & 0.643 & $<0.001$ & 163 \\
\hline Itatiaia vs Tinguá & 0.676 & $<0.001$ & 0.709 & $<0.001$ & 120 \\
\hline Itatiaia vs Sana & 0.722 & $<0.001$ & 0.652 & $<0.001$ & 248 \\
\hline Itatiaia vs Florianópolis & 0.734 & $<0.001$ & 0.733 & $<0.001$ & 686 \\
\hline
\end{tabular}

${ }^{a}$ The approximate geographical distances between localities in $\mathrm{km}$

different species [48]. On the other hand, all comparisons between Bocaina and Itatiaia, or between the four other populations yield much lower $F_{\mathrm{ST}}$ values (all below 0.35). These results suggest that the sampled populations belong to at least two independent evolutionary lineages, i.e. to different incipient species.

It is interesting to examine in more detail the $F_{\mathrm{ST}}$ data. The Clock pairwise $F_{\mathrm{ST}}$ values comparing Itatiaia with Bocaina and also those values comparing the populations from Group 1 were usually under 0.08 and most of them were not statistically significant. Using the cpr gene, albeit most of them significant, the pairwise $F_{\mathrm{ST}}$ values among Guapimirim, Tinguá and Sana (from Group 1) were low, usually under 0.16, while those between Florianópolis and these other three populations from Group 1 were moderately high (from 0.24 to 0.32 ). This differentiation of the Florianópolis population is somewhat expected, given that it is located $\sim 800 \mathrm{~km}$ away from the remaining ones, whereas Guapimirim, Tinguá and Sana are at most $130 \mathrm{~km}$ apart. However, the differentiation among An. cruzii populations cannot be explained by a simple isolation by distance model: the correlation between pairwise $F_{\mathrm{ST}}$ values and geographical distance was low and statistically non-significant for both genes (cpr: $r=0.127$, $P=0.22$; Clock: $r=-0.097, P=0.46$ ).

\section{Haplotype genealogies}

In order to gain a deeper insight on the differentiation of the An. cruzii populations, phylogenetic trees of the alleles were generated under the Bayesian Inference method for the two genes, $c p r$ and Clock (Figs. 2 and 3). In both trees, the most basal split separated the An. cruzii haplotypes in two large groups (henceforth called Groups 1 and 2) with posterior probabilities (pp) of $82 \%$ for cpr and $100 \%$ for Clock.

Group 1 was composed mainly of sequences obtained from individuals from the coastal side of Serra do Mar mountain range (Sana, Guapimirim and Tinguá) and was the same occurring in Florianópolis (South Brazil). Group 2 was composed exclusively by sequences from Itatiaia and Bocaina individuals in both trees. Hence the phylogenetic trees agree with the $F_{\mathrm{ST}}$ data analysed in the previous section, i.e. the sampled An. cruzii populations belong to at least two incipient species (Group 1 and Group 2) that cannot be distinguished morphologically, at least using the available taxonomic keys.

\section{Sympatry of group 1 and group 2 haplotypes in the Bocaina population}

The phylogenetic analyses disclosed another interesting phenomenon: the Bocaina population, which was sampled for the first time in the present study, contained Group 1 and Group 2 haplotypes for both genes (Figs. 2 and 3), i.e. the incipient species would be sympatric there. This allows an additional test for the hypothesis that Group 1 and Group 2 correspond to different species: if this is true, it is possible (although not mandatory) that we will find deviations from the HardyWeinberg equilibrium (namely, reduced amount of heterozygotes) due to partial reproductive isolation. Indeed, we observed 6 individuals $c p r_{1} / c p r_{1}, 5 c p r_{2} / c p r_{2}$ and 1 $c p r_{1} / c p r_{2}$, whereas the expected counts are 3.5, 2.5 and 6 , respectively $\left(\chi^{2}=8.4, d f=1, P=0.004\right)$. For the Clock gene, the heterozygote deficiency is less pronounced and not statistically significant (observed: 1 Clock $_{1} /$ Clock $_{1}, 13$ Clock $_{2} /$ Clock $_{2}$ and 2 Clock $/$ Clock $_{2}$; expected: 0.25 Clock $_{1} /$ Clock $_{1}, 12.25$ Clock $_{2} /$ Clock $_{2}$ and 3.5 Clock $_{1} /$ Clock $_{2}$, respectively; $P>0.05$ ). The most probable explanation for the deficiency of heterozygotes in sympatry is reproductive isolation [49].

It is important to note that the Bocaina population does not represent a simple scenario of two completely isolated species: we observed one $c p r_{1} / c p r_{2}$ heterozygote (individual Boc13, which would be a hybrid; marked with a purple dashed arrow in Fig. 2), and two Clock $_{1} /$ Clock $_{2}$ heterozygotes (Boc07 and Boc08; purple and orange dashed arrows in Fig. 3). The overall frequency of hybrids would be around 10\% (1 out 12 for $c p r ; 2$ out 16 for Clock). Furthermore, the Clock and cpr genotypes are not always coherent in Bocaina individuals (namely, individuals 19 and 20 are $c p r_{1} / c p r_{1}$ and $\left.\mathrm{Clock}_{2} / \mathrm{Clock}_{2}\right)$, which is compatible with introgression or 


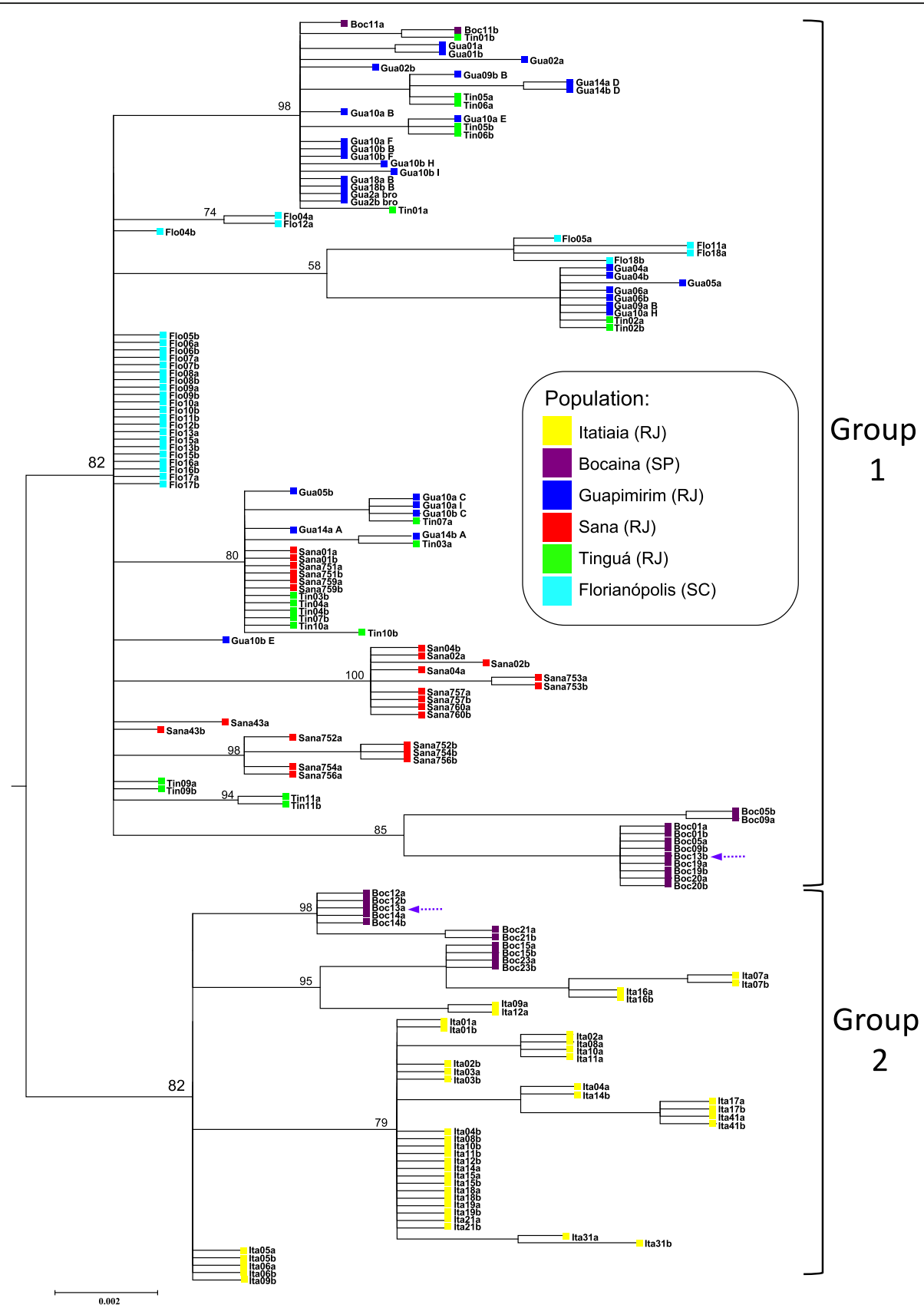

Fig. 2 Bayesian inference analysis tree based on cpr sequences (SYM $+G$ model). Genealogical relationships of the haplotypes show that at least two distinct Anopheles cruzii groups (1 and 2) occur in Rio de Janeiro State. Posterior probability values are represented above nodes. Lowercase letters in the haplotype names specify the two alleles ( $a$ or $b$ ) obtained from each individual. Purple dashed arrows indicate haplotypes from distinct groups (1 or 2) occurring in the same individual (GenBank accession numbers for all samples of cpr tree: KT724974-T725093, GU072619-GU072646 and GU072709-GU072730)

incomplete lineage sorting [49]. This complex scenario of partial isolation and differential introgression is similar to what has been observed in other anopheline species [50, 51]. Further studies of An. cruzii populations, particularly focusing in Bocaina and using a broader range of markers, are necessary to better understand the phenomenon.

\section{Fixed differences in cpr sequences}

All variations in the cpr gene occurred in the intron, which shows a number of polymorphic indels and microsatellites (Additional file 2). The analysis of these polymorphisms showed that fixed differences are present between individuals from Groups 1 and 2. Table 2 shows the number of copies of each repeat in An. cruzii studied 


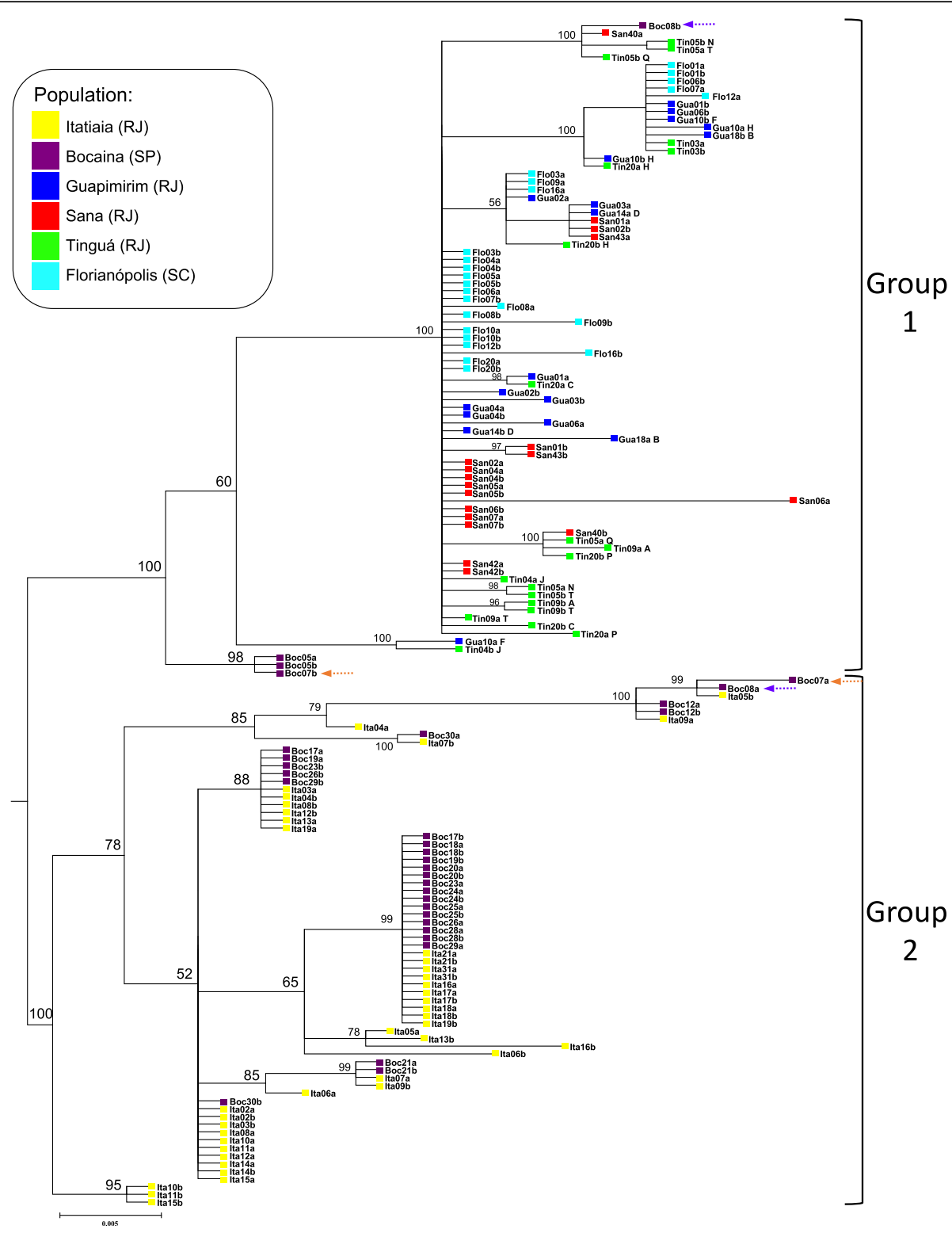

Fig. 3 Bayesian inference analysis tree based on Clock sequences (F81 $+\mathrm{G}$ model). Genealogical relationships of the haplotypes show that at least two distinct Anopheles cruzii groups (1 and 2) occur in Rio de Janeiro State. Posterior probability values are represented above nodes. Lowercase letters in the haplotype names specify the two alleles ( $a$ or $b$ ) obtained from each individual. Purple and orange dashed arrows indicate haplotypes from distinct groups (1 or 2) occurring in the same individual (GenBank accession numbers for all samples of Clock tree: KT725094-KT725197, JX129234-JX129257 and GU016402-GU016425)

populations. All individuals from Itatiaia have AAA at position 18, whereas all individuals from the four populations from Group 1 have AA. In Bocaina, both repeat patterns occur: Bocaina sequences from Group 2 are AAA and those from Group 1 are AA. Individuals from Florianópolis, Sana, Guapimirim and Tinguá have two to three "CG" repeats at position 21 and six to nine "CT" repeats at position 147, whereas in Itatiaia all individuals have just one "CG" and four "CT" repeats. Once again Bocaina looks somewhat intermediate: individuals from there have one or two "CG" repeats and four to seven
"CT" repeats. Fixed differences data are summarised in Table 2.

\section{Discussion}

Several studies have shown significant differentiation among An. cruzii populations [8, 12-24]. We found that at least two independent An. cruzii groups (probably incipient species) occur in South and South-East Brazillian Atlantic Rainforests: Group 1 encompasses populations from Florianópolis, Guapimirim, Tinguá and Sana as well as part of the Bocaina sample, and Group 2 is 
Table 2 Microsatellite repeat polymorphisms in cpr sequences from individuals of distinct localities reveals fixed differences. Repeat polymorphisms were identified in the cpr sequences from individuals sampled in distinct localities. Itatiaia sequences have fixed differences $\left[(A)_{3},(C G)_{1},(C T)_{4}\right]$ when compared with those from Florianópolis, Guapimirim, Tinguá and Sana $\left[(A)_{2,}(C G)_{2-3},(C T)_{6-9}\right]$. In Bocaina, both repeat patterns co-occur. Based on Additional file $2_{1}(A)_{2-3}$ repeats are located between positions 18 to 20, $(C G)_{1-3}$ between 21 to 26 and $(C T)_{4-9}$ between 147 to 164 positions

\begin{tabular}{llll}
\hline Locality & \multicolumn{3}{l}{ Number of repeats } \\
\cline { 2 - 4 } & $\mathrm{A}$ & $\mathrm{CG}$ & $\mathrm{CT}$ \\
\hline Florianópolis & 2 & 2 & $6-9$ \\
Guapimirim & 2 & 2 & $6-8$ \\
Tinguá & 2 & 2 & $6-8$ \\
Sana & 2 & $2-3$ & $7-8$ \\
Bocaina & $2-3$ & $1-2$ & $4-7$ \\
Itatiaia & 3 & 1 & 4 \\
\hline
\end{tabular}

composed of Itatiaia and the remainder of the Bocaina sample. There is good evidence that the distinction between Group 1 and Group 2 is real and biologically meaningful: (i) it is the deepest node in the haplotype phylogeny of both cpr and Clock genes, with strong statistical support (pp of 82 and 100\%, respectively); (ii) there are fixed differences between them (Table 2); (iii) Group 1 and Group 2 occur in sympatry in Bocaina and we found a statistically significant deficiency in heterozygote frequency for the $c p r$ gene, indicating partial reproductive isolation; (iv) the genetic divergence between Group 1 and Group 2 populations is very high, with an average $F_{S T}$ of 0.57 (Table 1). Such differentiation is greater than expected within a single evolutionary lineage without any kind of reproductive isolation; $F_{S T}$ values above 0.35 usually correspond to different species [48]. Our data reject the scenario of a single species with broad distribution in which physically distant populations are more differentiated (i.e. a simple isolation by distance model). For example, Tinguá is $120 \mathrm{~km}$ apart from Itatiaia and $750 \mathrm{~km}$ apart from Florianópolis, and yet the population from this locality is genetically much more similar to Florianópolis (Table 1); overall, there was no significant correlation between geographical and genetic distance $(r=0.127$ and -0.097 for cpr and Clock, respectively; Table 1). Hence, it seems safe to conclude that there are at least two different species in the sampled populations of An. cruzii. They are probably incipient species, since we observed Group 1 / Group 2 hybrids in the Bocaina population, where the two forms occur in sympatry. Overall, the An. cruzii case seems similar to that of the An. gambiae complex [51]: a complex of closely related species with partial introgression, which originates a patchwork of undifferentiated and differentiated genomic regions, with some markers showing more clear evidences of reproductive isolation (e.g.
rDNA "M" and "S" forms in An. gambiae; cpr "Group 1" and "Group 2" alleles in An. cruzii).

Further studies of An. cruzii populations, particularly focusing in Bocaina and using a broader range of markers, are clearly desirable, since there are many interesting open questions. For example, what is the introgression pattern across the An. cruzii genome? Are there additional species? A possible hint for this latter possibility is the observation of some differentiation within Group 1 haplotypes: the Bocaina sequences do not appear at random in cpr and Clock trees, but instead formed a well defined cluster with strong statistical support (Figs. 2 and 3). We are now pursuing these two questions.

The results presented here are consistent with previous studies. A study using allozymes as genetic markers concluded that no significant differences could be found between An. cruzii populations from Florianopolis (SC) and Tinguá (RJ) [18]. On the other hand, sequences from Itatiaia (SE) were distinct from those from Florianópolis (S) [24], which we confirmed here with a larger sample.

A question that warrants future studies is: what is the cause and history of the differentiation between Group 1 and Group 2 populations? Geographical distance per se is not a likely explanation. These mosquitoes strictly depend on bromeliad for their life-cycle, and the rainforests at the top of mountain ranges were mostly replaced by grassland during pre- and full-glacial times [52]. Thus, repeated periods of isolation in the last $2.5 \mathrm{Myr}$ between An. cruzii populations from the coastal slope of Serra do Mar (e.g. Tinguá) and Serra da Mantiqueira (e.g. Itatiaia) might have happened; such dynamics are known to have favoured speciation in groups as diverse as flatworms [53], harvestmen [54], snakes [55], frogs [56-60], primates [61-63], rodents [64], birds [65-67] and several malaria vectors [68]. Under this scenario, the Bocaina population, which is located midway between the coastal Serra do Mar and Serra da Mantiqueira populations, could be a zone of secondary contact between the incipient species, which typically is accompanied by hybridization and partial introgression $[69,70]$.

Another open question, this time with direct implications for human health, is: are there differences in the vectorial capacities of the distinct lineages of An. cruzii? To date, the autochthonous human malaria cases from RJ seem to be restricted to the coastal side of Serra do Mar mountains, where $A n$. cruzii is considered the main vector $[2,71,72]$. So, the knowledge about the co-occurrence of more than one lineage of An. cruzii in those mountains may have important implications for malaria control, especially if they are differentially involved in malaria transmission.

\section{Conclusions}

The analysis of genetic differentiation of cpr and Clock genes indicates that at least two evolutionarily 
independent lineages of An. cruzii (probably incipient species) occur in the Atlantic Forests of South-East Brazil. Individuals from these lineages present significant genetic divergence and fixed differences. One of these lineages, Group 1, occurs mainly on the coastal side of the Serra do Mar mountain range in altitudes below $600 \mathrm{~m}$ and Group 2 occurs in the inner sites of Serra do Mar and on the Serra da Mantiqueira mountains at higher altitudes (above $900 \mathrm{~m}$ ). The two groups occur in sympatry in the Bocaina population, where we found evidence for incomplete reproductive isolation.

\section{Additional files}

Additional file 1: Table S1. Source (adult/ bromeliad: reared in the laboratory) and sex of each sample used in this study. In Bocaina, captures of only adult females were performed; in Guapimirim and Sana, captures of only immatures were executed; and in Itatiaia and Tinguá, captures of both adults and immatures were carried out. $\hat{\delta}$, males; $;$, females;?, undetermined sex. (DOCX $15 \mathrm{~kb}$ )

Additional file 2: DNA sequences alignments of the cpr and Clock gene fragments from all Anopheles cruzii populations analysed. The introns are presented in the darkened regions. Dots represent the identity of the first nucleotide sequence. Abbreviations: Flo, individuals from Florianópolis; Boc Bocaina; Gua, Guapimirim; Ita, Itatiaia; San: Sana, Tin: Tinguá. (DOC 114 kb)

\section{Acknowledgements}

The authors are indebted to Dr Yara Maria Traub-Cseko and Dr. Pedro Lagerblad de Oliveira for their logistic support during this study, to Robson Costa da Silva for his technical assistance, to PDTIS-FIOCRUZ for the use of its DNA sequencing facility, to the Cartographic Engineer Jaime Pitaluga Neto for his technical support with Fig. 1, and to Sarah A. Kelly for kindly reviewing the English. We dedicate this manuscript to Alexandre Afranio Peixoto in memoriam. This paper is part of the Master thesis of Guilherme de Rezende Dias from the Graduation Program of Biodiversity and Evolutionary Biology at the Biology Institute, Federal University of Rio de Janeiro.

\section{Funding}

This work was supported by grants from the Howard Hughes Medical Institute (AAP), Wellcome Trust (ABC), FIOCRUZ (AAP, ANP, RLO, TFSN), CNPq and FAPERJ (LDRP, $A B C$ ) and Newton International Fellowship / Royal Society (LDPR).

\section{Availability of data and materials}

The datasets generated and/or analysed during the current study are available in the GenBank database under the accession numbers: KT724974-KT725197, GU072619-GU072646, GU072709-GU072730, GU016402-GU016425 and JX129234-JX129257.

\begin{abstract}
Authors' contributions
LDPR, GRD, TTSF and BFF participated in mosquitoes capturing, data generation and analysis. GRD also drafted the manuscript. ANP, CJCP, RLO and TFSN carried mosquito collections and morphological identification. LDPR, RLO and ABC helped in the paper drafting by critically reading the original manuscript. LDPR was the principal investigator, participated in its design and coordination. All authors read and approved the final manuscript.
\end{abstract}

\section{Ethics approval and consent to participate}

Not applicable

\section{Consent for publication}

Not applicable

\section{Competing interests}

The authors declare that they have no competing interests.

\section{Publisher's Note}

Springer Nature remains neutral with regard to jurisdictional claims in published maps and institutional affiliations.

\section{Author details}

'Universidade Federal do Rio de Janeiro, IB, PPGBBE, Rio de Janeiro, RJ, Brazil. ${ }^{2}$ Universidade Federal do Rio de Janeiro, Polo de Xerém, Duque de Caxias, RJ, Brazil. 'aboratório de Biologia Molecular de Insetos, IOC, FIOCRUZ, Rio de Janeiro, RJ, Brazil. ${ }^{4}$ Laboratório de Mosquitos Transmissores de Hematozoários, IOC, FIOCRUZ, Rio de Janeiro, RJ, Brazil. "5aboratório de Biologia Molecular de Parasitas e Vetores, IOC, FIOCRUZ, Rio de Janeiro, RJ, Brazil. ${ }^{6}$ Universidade Federal de Santa Catarina, MIP, CCB, Florianópolis, SC, Brazil. ${ }^{7}$ Departamento de Genética, Universidade Federal do Rio de Janeiro, Rio de Janeiro, RJ, Brazil. ${ }^{8}$ Department of Life Sciences, Imperial College London, London, UK. ${ }^{9}$ Universidade Federal de Santa Catarina, BEG, CCB, Florianópolis, SC, Brazil. ${ }^{10}$ Instituto Nacional de Ciência e Tecnologia em Entomologia Molecular (INCT-EM, CNPq), Rio de Janeiro, RJ, Brazil.

Received: 4 September 2017 Accepted: 2 January 2018

Published online: 15 January 2018

\section{References}

1. Ministério da Saúde/SVS - Sistema de Informação de Agravos de Notificação - Sinan Net. http://portalsinan.saude.gov.br/malaria. Accessed 10 May 2015.

2. De Pina-Costa A, Brasil P, Di Santi SM, De Araujo MP, Suárez-Mutis MC, Santelli ACFES, et al. Malaria in Brazil: what happens outside the Amazonian endemic region. Mem Inst Oswaldo Cruz. 2014;109:618-33.

3. de Câmara I G. Brief history of conservation in the Atlantic rainforest. In: GalindoLeal C, de Camara I G, editors. The Atlantic Forest of South America: biodiversity status, threats, and outlook. Washington: CABS and Island Press; 2003. p. 31-42.

4. Mittermeier R, Robles G, Hoffman M, Pilgrim J, Brooks T, Mittermeier C, et al. Hotspots revisited. Monterrey: CEMEX; 2004.

5. Myers N, Mittermeier R, Mittermeier C, Fonseca G, Kent J. Biodiversity hotspots for conservation priorities. Nature. 2000;403:853-8.

6. Zachos F, Habel J. Biodiversity hotspots: distribution and protection of conservation priority areas. New York: Springer Science \& Business Media; 2011.

7. Deane LM. Malaria vectors in Brazil. Mem Inst Oswaldo Cruz. 1986;81:5-14.

8. Zavortink TJ. Mosquito studies (Diptera, Culicidae) XXIX. A review of the subgenus Kerteszia of Anopheles. Contrib Am Entomol Inst. 1973;9:1-54.

9. Benchimol JL, Sá MR. Adolpho Lutz, Obra Completa: Febre amarela, malária \& protozoologia / Yellow Fever, Malaria \& Protozoology. Rio de Janeiro: Editora FIOCRUZ; 2005

10. Gadelha P. From "forest malaria" to "bromeliad malaria": a case-study of scientific controversy and malaria control. Parassitologia. 1994;36:175-95.

11. Marrelli MT, Malafronte RS, Sallum MA, Natal D. Kerteszia subgenus of Anopheles associated with the Brazilian Atlantic rainforest:current knowledge and future challenges. Malar J. 2007;6:127.

12. Deane LM, Deane MP, Ferreira Neto JA, Almeida FB. On the transmission of simian malaria in Brazil. Rev Inst Med Trop Sao Paulo. 1971;13:311-9.

13. Lorenz C, Marques TC, Anice M, Sallum M, Suesdek L. Altitudinal population structure and microevolution of the malaria vector Anopheles cruzii (Diptera:Culicidae). Parasit Vectors. 2014;7:581.

14. Ramírez CCL, Dessen EMB. Chromosomal evidence for sibling species of the malaria vector Anopheles cruzii. Genome. 2000;43:143-51.

15. Ramírez CCL, Dessen EMB. Cytogenetics analysis of a natural population of Anopheles cruzii. Brazilian J Genet. 1994;17:41-6.

16. Ramírez CCL, Dessen EMB. Chromosome differentiated populations of Anopheles cruzii : evidence for a third sibling species. Genetica. 2000;108:73-80.

17. Ramírez $\mathrm{CCL}$, Dessen EMB, Otto PA. Inversion polymorphism in a natural population of Anopheles cruzii. Caryologia. 1994;47:121-30.

18. Carvalho-Pinto CJ, Lourenço-de-Oliveira R. Isoenzimatic analysis of four Anopheles (Kerteszia) cruzii (Diptera: Culicidae) populations of Brazil. Mem Inst Oswaldo Cruz. 2004;99:471-5.

19. Malafronte RS, Marrelli MT, Carreri-Bruno G, Urbinatti PR, Marinotti O. Polymorphism in the second internal transcribed spacer (ITS2) of Anopheles (Kerteszia) cruzi (Diptera: Culicidae) from the state of São Paulo, Brazil. Mem Inst Oswaldo Cruz. 1997;92:306.

20. Malafronte RDS, Marrelli MT, Ramirez CCL, Nassar MN, Marinotti O. Intraspecific variation of second internal transcribed spacer of nuclear ribosomal DNA among populations of Anopheles (Kerteszia) cruzii (Diptera: Culicidae). J Med Entomol. 2007:44:538-42. 
21. Rona LDP, Carvalho-Pinto CJ, Mazzoni CJ, Peixoto AA. Estimation of divergence time between two sibling species of the Anopheles (Kerteszia) cruzii complex using a multilocus approach. BMC Evol Biol. 2010;10:91.

22. Rona LDP, Carvalho-Pinto CJ, Peixoto A. Evidence for the occurrence of two sympatric sibling species within the Anopheles (Kerteszia) cruzii complex in southeast Brazil and the detection of asymmetric introgression between them using a multilocus analysis. BMC Evol Biol. 2013;13:207.

23. Rona LDP, Carvalho-Pinto CJ, Gentile C, Grisard EC, Peixoto AA. Assessing the molecular divergence between Anopheles (Kerteszia) cruzii populations from Brazil using the timeless gene: further evidence of a species complex. Malar J. 2009;8:60.

24. Rona LDP, Carvalho-Pinto CJ, Peixoto AA. Molecular evidence for the occurrence of a new sibling species within the Anopheles (Kerteszia) cruzii complex in south-east Brazil. Malar J. 2010;9:33.

25. IBGE / Instituto Brasileiro de Geografia e Estatística. https://ww2.ibge.gov.br/ home/. Accessed 15 May 2016

26. Silva-do-Nascimento TF, Pitaluga LD, Peixoto AA, Lourenço-de-Oliveira R. Molecular divergence in the timeless and cpr genes among three sympatric cryptic species of the Anopheles triannulatus complex. Mem Inst Oswaldo Cruz. 2011;106:218-22

27. Hovemann BT, Sehlmeyer F, Malz J. Drosophila melanogaster NADPHcytochrome P450 oxidoreductase: pronounced expression in antennae may be related to odorant clearance. Gene. 1997;189:213-9.

28. Takken W, Knols BGJ. Odor-mediated behavior of afrotropical malaria mosquitoes. Annu Rev Entomol. 1999;44:131-57.

29. Allada R, White NE, So WV, Hall JC, Rosbash M. A mutant Drosophila homolog of mammalian clock disrupts circadian rhythms and transcription of period and timeless. Cell. 1998;93:791-804.

30. Maliti DV, Marsden CD, Main BJ, Govella NJ, Yamasaki Y, Collier TC, et al. Investigating associations between biting time in the malaria vector Anopheles arabiensis Patton and single nucleotide polymorphisms in circadian clock genes: support for sub-structure among An. arabiensis in the Kilombero Valley of Tanzania. Parasit Vectors. 2016;9:109.

31. Hilton $\mathrm{H}, \mathrm{Hey} J$. DNA sequence variation at the period locus reveals the history of species and speciation events in the Drosophila virilis group. Genetics. 1996;144:1015-25.

32. Bauzer LGSR, Souza NA, Ward RD, Kyriacou CP, Peixoto AA. The period gene and genetic differentiation between three Brazilian populations of Lutzomyia longipalpis. Insect Mol Biol. 2002;11:315-23.

33. Rund SSC, O'Donnell AJ, Gentile JE, Reece SE. Daily rhythms in mosquitoes and their consequences for malaria transmission. Insects. 2016;7:1-20.

34. Consoli RAGB, Oliveira RL. Principais mosquitos de importância sanitária no Brasil. Rio de Janeiro: SciELO - Editora FIOCRUZ; 1994

35. Jowett T. Preparation of nucleic acids. In: Roberts DB, editor. Drosophila: a practical approach. Oxford: IRL Press; 1998. p. 275-86

36. Thompson J, Gibson T. The CLUSTAL X windows interface: flexible strategies for multiple sequence alignment aided by quality analysis tools. Nucleic Acids Res. 1997;25:4876-82

37. Huelsenbeck JP, Ronquist F. MRBAYES: Bayesian inference of phylogenetic trees. Bioinformatics. 2001:17:754-5.

38. Ronquist F, Huelsenbeck JP. MrBayes 3: Bayesian phylogenetic inference under mixed models. Bioinformatics. 2003;19:1572-4.

39. Posada D. jModelTest: phylogenetic model averaging. Mol Biol Evol. 2008; 25:1253-6.

40. Borchsenius F. FastGap 1.2. Aarhus: Department of Biosciences, Aarhus University, Denmark; 2009

41. Figtree v.1.4.2. http/// tree.bio.ed.ac.uk/software/figtree/. Accessed 15 May 2016.

42. Filatov D. ProSeq: a software for preparation and evolutionary analysis of DNA sequence data sets. Mol Ecol Notes. 2002;2:621-4.

43. Excoffier L, Laval G, Schneider S. Arlequin (version 3.0): an integrated software package for population genetics data analysis. Evol Bioinformatics Online. 2007;1:47-50

44. Weir BS, Cockerham CC. Estimating F-statistics for the analysis of population structure. Soc Study Evol. 1984;38:1358-70.

45. Mantel $\mathrm{N}$. The detection of disease clustering and a generalized regression approach. Cancer Res. 1967;27:209-20

46. Chessel D, Dufour AB, Thioulouse J. The ade4 package-l-one-table methods. R News. 2004;4:5-10.

47. R Core Team. R: a language and environment for statistical computing. Vienna: R Foudation for Statistical Computing; 2014.
48. Hey J, Pinho C. Population genetics and objectivity in species diagnosis Evolution. 2012;66:1413-29.

49. Wondji C, Simard F, Fontenille D. Evidence for genetic differentiation between the molecular forms $\mathrm{M}$ and $\mathrm{S}$ within the Forest chromosomal form of Anopheles gambiae in an area of sympatry. Insect Mol Biol. 2002;11:11-9.

50. Coluzzi M, Sabatini A, Petrarca V, Di Deco MA. Chromosomal differentiation and adaptation to human environments in the Anopheles gambiae Complex. Trans R Soc Trop Med Hyg. 1979;73:483-97.

51. Fontaine MC, Pease JB, Steele A, Waterhouse RM, Neafsey DE, Sharakhov IV, et al. Extensive introgression in a malaria vector species complex revealed by phylogenomics. Science. 2015;347:6217.

52. Behling $\mathrm{H}$. South and southeast Brazilian grasslands during late quaternary times: a synthesis. Palaeogeogr Palaeoclimatol Palaeoecol. 2002;177:19-27.

53. Álvarez-Presas M, Sánchez-Gracia A, Carbayo F, Rozas J, Riutort M. Insights into the origin and distribution of biodiversity in the Brazilian Atlantic forest hot spot: a statistical phylogeographic study using a low-dispersal organism. Heredity. 2014;112:656-65.

54. Pinto-da-Rocha R, da Silva MB, Bragagnolo C. Faunistic similarity and historic biogeography of the harvestmen of southern and southeastern Atlantic rain forest of Brazil. J Arachnol. 2005;33:290-9.

55. Grazziotin FG, Monzel M, Echeverrigaray S, Bonatto SL. Phylogeography of the Bothrops jararaca Complex (Serpentes: Viperidae): past fragmentation and island colonization in the Brazilian Atlantic Forest. Mol Ecol. 2006;15: 3969-82.

56. Carnaval AC, Hickerson MJ, Haddad CFB. Stability predicts genetic diversity in the Brazilian Atlantic forest hotspot. Science. 2009;323:785-9.

57. Fitzpatrick SW, Brasileiro C, Haddad CFB, Zamudio KR. Geographical variation in genetic structure of an Atlantic coastal Forest frog reveals regional differences in habitat stability. Mol Ecol. 2009;18:2877-96.

58. Martins FM. Historical biogeography of the Brazilian Atlantic forest and the Carnaval-Moritz model of Pleistocene refugia: what do phylogeographical studies tell us? Biol J Linn Soc. 2011:104:499-509.

59. Thomé MTC, Zamudio KR, Giovanelli JGR, Haddad CFB, Baldissera F, Alexandrino J. Phylogeography of endemic toads and post-Pliocene persistence of the Brazilian Atlantic Forest. Mol Phylogenet Evol. 2010;55: 1018-31.

60. Vasconcelos TS, Prado VHM, da Silva FR, Haddad CFB. Biogeographic distribution patterns and their correlates in the diverse frog fauna of the Atlantic forest hotspot. PLoS One. 2014;9:8.

61. Buckner JC, Lynch Alfaro J, Rylands AB, Alfaro ME. Biogeography of the marmosets and tamarins (Callitrichidae). Mol Phylogenet Evol. 2015:82:413-25.

62. Cortés-Ortiz L, Bermingham E, Rico C, Rodríguez-Luna E, Sampaio I, RuizGarcía M. Molecular systematics and biogeography of the Neotropical monkey genus, Alouatta. Mol Phylogenet Evol. 2003;26:64-81.

63. Marroig G, Cropp S, Cheverud JM. Systematics and evolution of the Jacchus group of marmosets (Platyrrhini). Am J Phys Anthropol. 2004;123:11-22.

64. Valdez L, D'Elía G. Differentiation in the Atlantic Forest: phylogeography of Akodon montensis (Rodentia, Sigmodontinae) and the Carnaval-Moritz model of Pleistocene refugia. J Mammal. 2013;94:911-22.

65. Cabanne GS, Santos FR, Miyaki CY. Phylogeography of Xiphorhynchus fuscus (Passeriformes, Dendrocolaptidae): Vicariance and recent demographic expansion in southern Atlantic forest. Biol J Linn Soc. 2007;91:73-84.

66. Chaves AV, Freitas GHS, Vasconcelos MF, Santos FR. Biogeographic patterns, origin and speciation of the endemic birds from eastern Brazilian mountain tops: a review. Syst Biodivers. 2015:13:1-16.

67. Dantas GPM, Sari EHR, Cabanne GS, Pessoa RO, Marini MÂ, Miyaki CY, et al. Population genetic structure of the Atlantic Forest endemic Conopophaga lineata (Passeriformes: Conopophagidae) reveals a contact zone in the Atlantic Forest. J Ornithol. 2014:156:85-99.

68. Loaiza JR, Bermingham E, Sanjur OI, Scott ME, Bickersmith S, Conn JE. Review of genetic diversity in malaria vectors (Culicidae: Anophelinae). Infect Genet Evol. 2012;12:1-12.

69. Bay RA, Ruegg K, Bay RA. Genomic islands of divergence or opportunities for introgression? Proc R Soc B. 2017;284:20162414.

70. Canestrelli D, Porretta D, Lowe WH, Bisconti R, Carere C, Nascetti G. The tangled evolutionary legacies of range expansion and hybridization. Trends Ecol Evol. 2016;31:677-88. 
71. Miguel RB, Peiter PC, De Albuquerque H, Coura JR, Moza PG, Costa ADP, et al. Malaria in the state of Rio de Janeiro, Brazil, an Atlantic Forest area: an assessment using the health surveillance service. Mem Inst Oswaldo Cruz. 2014;109:634-40.

72. Lorenz C, Virginio F, Aguiar BS, Suesdek L, Chiaravalloti-Neto F. Spatial and temporal epidemiology of malaria in extra-Amazonian regions of Brazil. Malar J. 2015;14:408.

Submit your next manuscript to BioMed Central and we will help you at every step:

- We accept pre-submission inquiries

- Our selector tool helps you to find the most relevant journal

- We provide round the clock customer support

- Convenient online submission

- Thorough peer review

- Inclusion in PubMed and all major indexing services

- Maximum visibility for your research

Submit your manuscript at www.biomedcentral.com/submit 